\title{
"The level of financial inclusion in Ukraine: Measuring access, quality, and usage
}

of financial products and services"

\begin{tabular}{ll} 
& Yuliia Shapoval (iD \\
AUTHORS & $\begin{array}{l}\text { Andrii Shkliar (D) } \\
\text { Oleksii Shpanel-Yukhta (D) } \\
\text { Kateryna Gruber (I) }\end{array}$ \\
& $\begin{array}{l}\text { Yuliia Shapoval, Andrii Shkliar, Oleksii Shpanel-Yukhta and Kateryna Gruber } \\
(2021) . \text { The level of financial inclusion in Ukraine: Measuring access, quality, and } \\
\text { usage of financial products and services. Banks and Bank Systems, 16(2), 59-67. } \\
\text { doi:10.21511/bbs.16(2).2021.06 }\end{array}$ \\
\hline ARTICLE INFO & http://dx.doi.org/10.21511/bbs.16(2).2021.06 \\
\hline DOI & Thursday, 13 May 2021 \\
\hline RELEASED ON & Wednesday, 07 April 2021 \\
\hline RECEIVED ON & Wednesday, 05 May 2021 \\
\hline ACCEPTED ON & (c) EY \\
\hline LICENSE & Lis work is licensed under a Creative Commons Attribution 4.0 International \\
\hline JOURNAL & "Banks and Bank Systems" \\
\hline ISSN PRINT & $1816-7403$ \\
\hline ISSN ONLINE & $1991-7074$ \\
\hline PUBLISHER & LLC "Consulting Publishing Company "Business Perspectives" \\
\hline FOUNDER & LLC "Consulting Publishing Company "Business Perspectives" \\
\hline
\end{tabular}

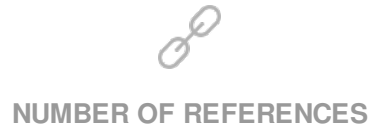

24
NUMBER OF FIGURES

1
NUMBER OF TABLES

1

(C) The author(s) 2021. This publication is an open access article. 


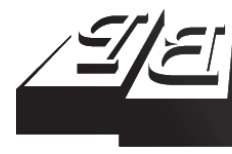

BUSINESS PERSPECTIVES

(2)

LLC "CPC "Business Perspectives"

Hryhorii Skovoroda lane, 10, Sumy, 40022, Ukraine

www.businessperspectives.org

Received on: $7^{\text {th }}$ of April, 2021 Accepted on: $5^{\text {th }}$ of May, 2021 Published on: $13^{\text {th }}$ of May, 2021

() Yuliia Shapoval, Andrii Shkliar, Oleksii Shpanel-Yukhta, Kateryna Gruber, 2021

Yuliia Shapoval, Ph.D. in Economics, Research Fellow, Department of Monetary Relations, Institute for Economics and Forecasting, National Academy of Sciences of Ukraine, Ukraine. (Corresponding author)

Andrii Shkliar, Ph.D. in Economics, Senior Research Fellow, Department of Monetary Relations, Institute for Economics and Forecasting, National Academy of Sciences of Ukraine, Ukraine.

Oleksii Shpanel-Yukhta, Ph.D. in Economics, Junior Research Fellow, Department of Monetary Relations, Institute for Economics and Forecasting, National Academy of Sciences of Ukraine, Ukraine.

Kateryna Gruber, Ph.D. in Economics, Senior Research Fellow, Department of Monetary Relations, Institute for Economics and Forecasting, National Academy of Sciences of Ukraine, Ukraine.
Yuliia Shapoval (Ukraine), Andrii Shkliar (Ukraine), Oleksii Shpanel-Yukhta (Ukraine), Kateryna Gruber (Ukraine)

\begin{abstract}
While financial inclusion is seen as a goal of socio-economic development, there is still no clear understanding of how to measure it. Following this concern, the paper deals with the computation of the financial inclusion index of the Ukrainian economy using an annual dataset spanning from 2008 to 2020 and following the Sarma methodology. The object of the study is a set of indicators of usage, access and quality of financial products and services. The obtained results demonstrate the medium level of financial inclusion. The improvement of financial inclusion is observed in 2012, 2013, 2020 (namely $0.55-0.56$ in the range of 0 and 1). From 2015 (0.38) till $2018(0.39)$, the revealed downward trend affirms that the withdrawal of banks from the market has deteriorated the level of quality and usage of financial products and services. Financial inclusion declined during the cleaning up of the banking system in 2014-2016, just as it did after the global financial crisis in 2009-2010. Despite the development of the payment infrastructure, there is a need to diversify access, increase quality, and quicken the usage of financial products and services due to existing distrust in national financial institutions. Improving financial literacy and consumer protection, and closing regulatory gaps in the non-banking sector are seen as ways to enhance financial inclusion. Thus, financial regulators should establish an upward trend in financial inclusion that will ensure full access to formal financial services and will not adversely affect the stability of financial system.
\end{abstract}

\section{Keywords}

JEL Classification

\section{INTRODUCTION}

Nowadays, financial inclusion is one of the critical drivers of socio-economic development, as evidenced by the growing interest of governments in research concerning its various aspects and preconditions, as well as strategies for its implementation. Over the past three years, the Ukrainian payment infrastructure has been actively developed within the financial inclusion target, declared by the National Bank of Ukraine as a medium-term strategy (NBU, 2021). Further, the pandemic and the introduction of quarantine measures have accelerated the transition to digital services and non-cash transactions. However, there are many violations of consumer rights, unfair business activities, and evasion of the Law on Financial Services. Globally and in Ukraine, the most popular method of payment card fraud is social engineering. For instance, consumers continue to receive calls in which fraudsters introduce themselves as employees of a bank or even the National Bank of Ukraine and provide false information about card blocking. This problem highlights the need for improving the level of 
consumers' financial literacy about financial products and services as an instrument to enhance financial inclusion. Hence, distrust in financial institutions remains the main barrier to the active usage of financial products and services. That leads to the financial exclusion of the financially inexperienced population. The results of the nationwide survey of Ukrainian consumers of financial products and services (Deposit Guarantee Fund, 2020) represented that the respondents "who keep more than half of their funds with a bank" increased from $8 \%$ to $13 \%$. Although the confidence in banks is gradually being restored, the interest of Ukrainians in financial products and services has decreased. In 2017, 63\% of the respondents indicated an interest in financial products and services against $37 \%$ of those who were "rather not interested", whereas, in 2019, this balance was 58\% against $42 \%$. Also, $22 \%$ of the respondents said they had no bank accounts at all. This is explained by the fact that the change in trust in financial institutions is closely correlated with the uncertainty in the financial market (Anufriieva \& Shapoval, 2019).

As regulation of microfinance organizations in Ukraine is weaker than banking regulation, hyper access of short-term cash lending has become a risk for the population's usage of financial services and products. Liberal legislation and requirements led to the extension of the number of microfinance companies. As of March 2021, there were 73 banks and 2,009 non-banking financial services participants (National Bank of Ukraine, 2021). The functioning of such a large number of companies focusing on short-term high-margin cash income poses a threat of trust in borrowing instruments. In turn, regulation of consumer protection and market players' interaction can foster financial inclusion. Enhancement of financial institutions and credit information exchange adds to infrastructure development indicators and the extensive use of deposit accounts per capita (Claessens \& Rojas-Suarez, 2016). Besides, new channels of financial services, such as mobile and electronic banking, are swiftly emerging. Also, Chen and Divanbeigi (2019) point out that individuals are more likely to have accounts with a financial institution in countries that follow best regulatory practices.

In this regard, the design of policy measures to enhance financial inclusion necessitates, first and foremost, the assessment of the extent of progress on financial inclusion. The level of financial inclusion will demonstrate whether the financial system maximizes the usage and access to financial products and services, while minimizing the impact of barriers to financial inclusion for the unbanked population, and therefore improving the quality of financial products and services.

\section{LITERATURE REVIEW}

Over the last decade, approaches to assessing financial inclusion have been actively developed by researchers. The concept itself was first formally defined at the Global Partnership for Financial Inclusion conference by five key standard-setting bodies. Later, the concept of financial inclusion underwent different interpretations by financial market participants as a process, stage or state of financial development. The scientific community determines financial inclusion through its key dimensions: access (availability), usage and quality (effect or penetration) of financial products and services. Most previous studies define financial inclusion as the access and effective use of a range of relevant products and services provided in a well-regulated environment, where consumer protection exists. For example, financial inclusion means "the process that ensures the ease of access, availability and usage of the formal financial system for all members of an economy" (Sarma, 2008, p. 3) or "an economic state where individuals and firms are not denied access to basic financial services based on motivations other than efficiency criteria" (Amidzic et al., 2014, p. 5). This paper considers financial inclusion as a process of interaction of financial market participants and consumers of financial products and services, which, through the provision of equal access to financial products and services, ensures the involvement of the population in the financial market.

In the present studies, the measurement of financial inclusion has evolved from compiling cross-country indicators to assessing the impact 
of financial inclusion on the economic development. Nonetheless, one of the tough challenges for all researchers is that empirical data linking access to financial products and services to economic development requires consistent information. Beck et al. (2009) note that "most of the evidence concerning the causal links between financial development, growth, and poverty comes from aggregate data using, for example, financial depth measures rather than outreach or access measures" (p. 122). In other words, data about financial inclusion dimensions is limited either by the lack of comparability between survey tools or incomplete information due to the absence of micro statistics.

Sarma $(2008,2012)$ made one of the first attempts to calculate the aggregate financial inclusion index, which covered information on the availability, usage and penetration of banking services, and used statistics comparable across countries over time. Sarma applied the Euclidian distance approach to calculate the financial inclusion index, unlike the UNDP method used by the average approach. The analysis indicated that "a large number of economies, including several industrial economies, have low levels of financial inclusion" (p. 19). Herewith, she acknowledged that her financial inclusion index suffered "from loss of country-specific information owing to the aggregative nature of the data" (p. 14). This factor disabled to consider "affordability, timeliness and quality of the financial services" (Sarma, 2008, p. 19). Later, Sarma (2012) determined another limitation in measuring the financial index. It referred to the change in traditional banking, namely "technological advancements, improvements in infrastructure and higher levels of education minimize the role of a bank branch being and increase the role of technology-driven service outlets" (p. 31). This research confirmed that "financial inclusion and income levels tend to move in the same direction" (Sarma, 2012, p. 32).

Like as in the case of Sarma's measurement approach, Chakravarty and Pal (2010) assumed that all dimensions had the same impact on financial inclusion. However, their assessment improved upon the Sarma's index (2008) by applying an axiomatic approach. The percentage contribution of the functioning dimension allowed identifying those dimensions, which were "more or less sensitive to financial inclusion" (Charkravarty \& Pal,
2010, p. 9). Thus, their results cast a new light on calculating the weights of different dimensions of the overall inclusion index.

In contrast to the non-parametric method of Sarma and Chakravarty and Pal, Amidzic et al (2014) did not assign equal weights to all variables and dimensions while compiling aggregated indices. Their composite index used a parametric method through factor analysis to determine the weight of each dimension, "permitting proper weight assignment, while the weighted geometric mean is an appropriate aggregator of imperfect substitutes" (Amidzic et al., 2014, p. 23).

Although Camara and Tuesta (2014) also used a parametric method, they employed a two-stage principal component analysis (PCA) to assign weights endogenously to the dimensions. At first, the authors estimated sub-indices rather than the overall index of financial inclusion. Then they applied "again PCA to estimate the overall index by using the previous sub-indices as causal variables" (p. 2). According to the authors, access is the most critical parameter for measuring financial inclusion, and the latter is "highly correlated with GDP per capita, education, financial system efficiency, and financial stability" (Camara \& Tuesta, 2014, p. 22).

Following Camara and Tuesta (2014), Park and Mercado (2018) used two-stage PCA and simultaneously computed Sarma's dimensions. As soon as they obtained the dimension sub-indices, they ran another PCA to assign weights for the financial inclusion index. Their results demonstrated that countries "with high financial inclusion have significantly lower poverty rates". That allowed authors to substantiate "the causal inverse relation between financial access and poverty at the individual and household level on a cross- country setting" (p. 2). Besides, the higher the level of financial inclusion is, the more it depends on higher output growth and lower poverty levels in highand middle-high-income countries. However, this interrelation is weaker in the middle-, low- and low-income countries due to specific factors (Park \& Mercado, 2018).

Applying Sarma's index, Nuzzo and Piermattei (2019) estimated the weights endogenously through principal component analysis. Stating 
that existing financial inclusion indices included wrong variables or ignored some aspects of financial inclusion, they paid attention to the role of electronic cards. The assessment of the level of financial inclusion changes when the distribution of electronic cards is taken into account. Because the latter "provide alternatives to usual saving practices by allowing to receive payments and store money and by allowing less costly economic transactions across larger markets and wider geographic areas" (Nuzzo \& Piermattei, 2019, p. 29).

In a recent empirical paper written by Mukherjee and Sood (2020), "as opposed to the exogenous weights assigning system in measuring financial inclusion indices used two-stage principal component analysis to measure the degree of financial inclusion disaggregating financial inclusion into usage, access and barriers dimensions" (p. 985). The authors admit that high-income and developed countries have the highest level of financial inclusion, which "leads to a comparatively higher likelihood of increasing GDP growth and lowering multi-dimensional poverty, and a higher female workforce participation for the countries having lowest and medium levels of financial inclusion" (Mukherjee \& Sood, 2020, p. 985). Likewise, Menyelim et al. (2021) show that financial inclusion contributes to reducing inequality, and hence "financially less developed economies stand to earn the most significant growth and equity gains from financial development" (Menyelim et al., 2021, p. 13).

The Ukrainian researchers focus mainly on the factors, risks and positive effects of population coverage with financial products and services in defining the level of financial inclusion. For example, Kornivska (2020), among the risks of financial inclusion, emphasizes that "the main long-term institutional risk for the financial inclusion development and noncash circulation is market participants' agreement to lose financial freedom in conditions of growing uncertainty of economic and social life and the problems of poverty". In turns, Dudynets and Vernei (2018) take into account factors of financial inclusion such as "a residence, limited knowledge of financial services, low level of financial literacy and income level, lack of legal identity, and distrust in financial institutions" (p. 10). The authors assert that enhancement of financial inclusion in Ukraine "should be based on improving quality of financial services through the usage of financial technology for consumers who already have access to these services, and expanding the provision of basic financial services to those who are financially excluded" (Dudynets \& Vernei, 2018, p. 12).

While the importance of financial inclusion is widely recognized by Ukrainian researchers, determining the level of coverage population with financial products and services is quite challenging, since sources of the government statistics and sociologic polls lack microdata integrity, limiting research in this field. In particular, Naumenkova (2014) employed the indicators of access to financial products and services from the World Bank and the IMF's data to assess the level of financial services coverage of the Ukrainian population. Berezhna and Snytuk (2019) examined the development of infrastructure for access to non-cash payments of the regions and highlighted the problems of poor financial literacy, as well as gaps in legislation to protect consumer rights. They concluded that although the financial inclusion of the Ukrainian economy corresponds to the global average level, the financial inclusion level in Ukraine lags significantly behind the indicators of highly developed countries. Prymostka et al. (2020), in their attempt to assess financial inclusion in Ukraine, used indicators calculated by the World Bank, which allowed them to compare the domestic level of financial inclusion with the levels in Poland, Georgia, Belarus and the Czech Republic in 2014 and 2017. The authors outlined that, in general, "the level of financial inclusion is growing, except the tendency to save, which indicates a low level of confidence in the banking system" (Prymostka et al., 2020, p. 507).

\section{AIMS}

This study aims to quantify the access to financial services and products, their quality and usage by the Ukrainian population. The paper discusses indicators that are not based on household and business surveys due to differences in their methodology. To objectively measure the dimensions of financial inclusion, the continuous official statistics of the National Bank of Ukraine is used when calculating the financial inclusion index, which demonstrates a more relevant and reliable picture of the level of financial inclusion. 


\section{METHODS}

For this study, the methods of analysis of coefficients and relative values were used. Construction of the index follows Sarma's approach $(2008,2012)$, covering the period from 2008 till 2020. At the first stage, the three sub-indices - access, usage and quality - were estimated. At the second stage, the overall financial inclusion index was computed using the dimensions as explanatory variables. Based on the fact that the model of the Ukrainian financial market is bank-centric, the indicators of the banking segment were used to calculate the current level of financial inclusion. Specifically, $87 \%$ of financial sector assets are embraced by the banking segment (as of September 2020, total assets of Ukrainian banks amounted to UAH 1,707.9 billion), and only about $13 \%$ belong to credit unions, pawn offices, financial and insurance companies (NBU, 2021).

The usage of financial products and services means the frequency and mechanisms of using an account in a financial institution for the accumulation of savings, lending, making payments and transferring remittances. "The information from the standpoint of public demand for financial services reflects each segment of the population's needs by financial service providers" (Shapoval, 2020 , p. 36). The sub-index of usage components includes data on the number of deposit accounts with commercial banks per 1,000 adults and the number of active payment cards per 1,000 adults.

The access is measured by the degree of supply of financial products and services and refers to customers' physical ability to reach a service point easily. The access sub-index implies data on the number of bank branches, ATMs, terminals per 100,000 adults, because the latter play an essential role in providing access not only to traditional cash services, but also to payment of bills and credit cards.

The quality dimension involves indicators of the penetration and popularity of non-cash payments such as retail deposits/GDP and corporate deposits/GDP, net retail loans /GDP and net corporate loans/GDP, the share of non-cash transactions in the total volume of transactions using payment cards (by amount).
In the calculations, the selection of indicators is determined by the availability of relevant and consistent input data. To obtain an average sub-index within the range of 0 to 1 , eight coefficients of financial inclusion with different units of measurement are transformed to create comparative input data. According to the min-max range method, a linear data conversion is performed in the range, where the minimum and maximum values correspond to 0 and 1 . The computation of the sub-index of each indicator is displayed in the equation:

$$
x^{\prime}(i)=\frac{x(i)-\min (x(i))}{\max (x(i)-\min (x(i))},
$$

where $x(i)$ - the actual value of indicator $i ; x^{\prime}(i)$ the normalized value of indicator $i$; and $\max (x(i)$ and $\min (x(i))$ - the maximum and the minimum value of indicator $i$.

Next, each sub-index is calculated by the formula of simple average of individual coefficients. Subsequently, the three sub-indices are combined into a cumulative financial inclusion indicator. To avoid subjectivity while allocating the appropriate weights, the equal importance of all dimensions was considered in the index of financial inclusion.

\section{RESULTS}

The index of financial inclusion (IFI) has values of 0 indicating complete financial exclusion and 1 indicating complete financial inclusion. As shown in Figure 1 , the level of financial inclusion of the Ukrainian economy is medium (according to Sarma's classification (2008): $0.5<$ IFI $\leq 1$ - high, $0.3 \leq$ IFI $<0.5$ - medium, and $0 \leq$ IFI $<0.3-$ low).

In general, the improvement of one or another dimension's performance leads to a higher value of the index. The maximum level of access, usage and quality of financial products and services is considered to be conducive for improving socio-economic development. The aggregate index of financial inclusion in Ukraine reached a maximum in 2013 and 2020 (0.56). The withdrawal of banks from the market from 2014 till 2018 led to a decline of all sub-indices. Since 2019, there has been significant progress in financial inclusion, most marked by usage and access dimensions. 


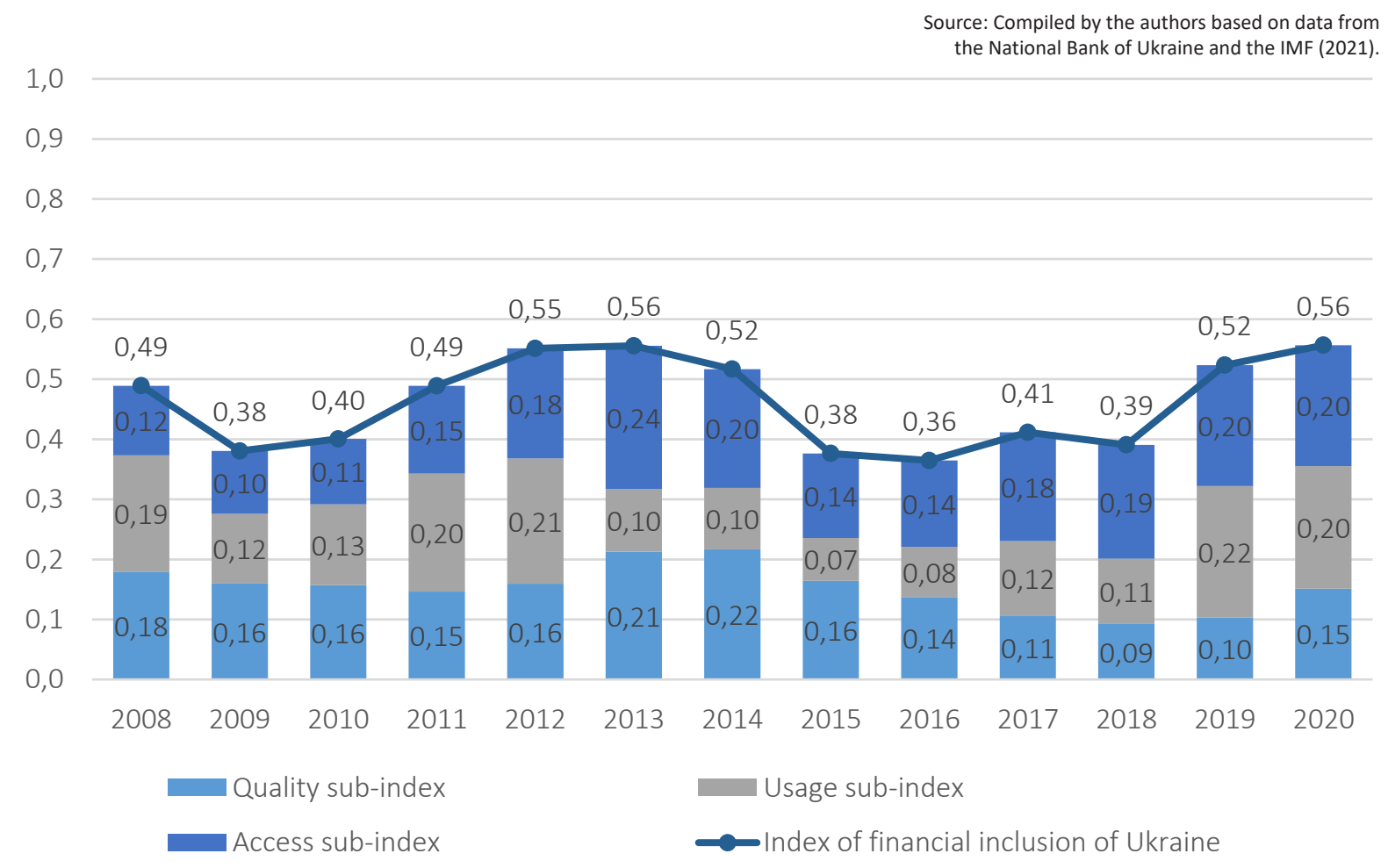

Figure 1. Index of financial inclusion of the Ukrainian economy, 2008-2020

During the analyzed period, banks actively expanded their acquiring networks (Table 1). Thus, in terms of access, there was progress in the number of ATMs, which increased (with a slight decrease in 2015-2016) to 83.57 units per 100,000 adults in 2020 (in 2008 - 60.6 units); in the number of payment terminals, which reached (with a slight decrease in 2014-2015) 928.49 units per 100,000 adults in 2020 (in 2008 - 253.01 units). At the same time, since 2009 , there has been a reduction in the number of bank branches from 49.79 units per 100,000 adults in 2008 to 17.15 units in 2020 . It was caused by the consequences of the 2008 crisis and by the recognition of more than 90 insolvent banks during 20142017. But the reduction in the banks' branch network was offset by ATMs and payment terminals' branching, which generally meant an increase in the access sub-index with a deterioration in 2014-2016. In 2020, access to financial products and services already exceeded the pre-crisis level of 2014 (0.56), illustrating a positive shift in financial development over the past two years.

The improved access dimension is partly due to the fact that in spring of 2018, the National Bank of Ukraine issued a license to the national postal operator to transfer funds in the national currency without opening an account. That enabled Ukrposhta to serve customers using payment cards. Ukroposhta is an essential channel of financial access as its network covers $100 \%$ of inhabited localities in Ukraine. It involves more than 11,000 postal facilities, which is almost $40 \%$ more than all banks' branches' coverage (Ukrposhta, 2021). The national postal operator can embrace financially excluded groups of the population. As of March 2021, Ukrposhta services 3.5 million retirees living in villages and cities where there is no bank branch or ATM. There are more than 27,000 such localities in Ukraine, wherein about 13 million people live (Ministry of Infrastructure of Ukraine, 2021).

The level of usage, in its turn, has decreased in the post-crisis years 2009-2010 and 2013-2016 (Table 1), which indicates the dependence of public demand for banking products and services on financial stability in the country. The number of active payment cards has been growing since 2008, with a slight slowdown in 2014-2015, and it made up 972.62 units per 1,000 adults in 2020 (in 2008 - 836 units). The number of deposit accounts with banks had been increasing until 2012, and it amounted to 3191.59 units per 1,000 adults in 2020 (in 2008 - 3860.3 units).

The dynamics of quality indicators also depends on public confidence in the domestic banking sys- 
Table 1. Dimensions of the Ukrainian financial inclusion level, 2008-2020

Source: Compiled by the authors based on data from the National Bank of Ukraine and the IMF (2021).

\begin{tabular}{|c|c|c|c|c|c|c|c|c|}
\hline \multirow[b]{2}{*}{ Year } & \multicolumn{3}{|c|}{ Access } & \multicolumn{2}{|l|}{ Usage } & \multicolumn{3}{|c|}{ Quality } \\
\hline & $\begin{array}{c}\text { ATMs } \\
\text { per } 100 \\
\text { thousand } \\
\text { adults, } \\
\text { units }\end{array}$ & $\begin{array}{c}\text { Terminals } \\
\text { per } 100 \\
\text { thousand } \\
\text { adults, } \\
\text { units }\end{array}$ & $\begin{array}{c}\text { Bank } \\
\text { branches } \\
\text { per } 100 \\
\text { thousand } \\
\text { adults, } \\
\text { units }\end{array}$ & $\begin{array}{l}\text { Active payment cards per } \\
1,000 \text { adults: at least } 1 \\
\text { withdrawal transaction } \\
\text { during the reporting period } \\
\text { (till April } 1,2012 \text { - for } \\
\text { the latest } 12 \text { months, till } \\
\text { January } 1,2020 \text { - for the } \\
\text { latest } 3 \text { months) }\end{array}$ & $\begin{array}{l}\text { Deposit } \\
\text { accounts } \\
\text { with banks } \\
\text { per } 1,000 \\
\text { adults }\end{array}$ & $\begin{array}{c}\text { Retail } \\
\text { deposits/ } \\
\text { GDP + } \\
\text { corporate } \\
\text { deposits/ } \\
\text { GDP }\end{array}$ & $\begin{array}{l}\text { Net retail } \\
\text { loans/ } \\
\text { GDP+ net } \\
\text { corporate } \\
\text { loans/GDP }\end{array}$ & $\begin{array}{c}\text { Non-cash } \\
\text { transactions } \\
\text { in total } \\
\text { volume of } \\
\text { transactions } \\
\text { with the use } \\
\text { of payment } \\
\text { cards (by } \\
\text { amount) }\end{array}$ \\
\hline 2008 & 60.6 & 253.01 & 49.79 & 836 & $3,860.3$ & 0.39 & 0.71 & 0.05 \\
\hline 2009 & 62.96 & 224.23 & 45.2 & 633.21 & $4,029.97$ & 0.36 & 0.67 & 0.05 \\
\hline 2010 & 65.89 & 236.22 & 42.49 & 642.33 & $4,221.66$ & 0.39 & 0.56 & 0.07 \\
\hline 2011 & 72.31 & 270.72 & 44.39 & 763.69 & 4,316 & 0.38 & 0.51 & 0.08 \\
\hline 2012 & 79.36 & 357.22 & 43.1 & 726.76 & $4,693.63$ & 0.4 & 0.47 & 0.12 \\
\hline 2013 & 88.83 & 486.99 & 42.46 & 784.17 & $2,989.72$ & 0.46 & 0.52 & 0.17 \\
\hline 2014 & 85.25 & 474.76 & 35.13 & 769.7 & $3,052.2$ & 0.43 & 0.54 & 0.25 \\
\hline 2015 & 77.96 & 454.81 & 27.76 & 721.17 & $2,929.73$ & 0.38 & 0.36 & 0.31 \\
\hline 2016 & 79.31 & 514.79 & 24.26 & 760.58 & $2,860.95$ & 0.36 & 0.23 & 0.36 \\
\hline 2017 & 87.3 & 593.78 & 22.39 & 822.4 & $3,034.45$ & 0.3 & 0.18 & 0.39 \\
\hline 2018 & 86.79 & 705.2 & 20.19 & 876.55 & $2,509.2$ & 0.26 & 0.16 & 0.45 \\
\hline 2019 & 85.75 & 831.81 & 19.1 & 1006.09 & $3,191.59$ & 0.27 & 0.14 & 0.5 \\
\hline 2020 & 83.57 & 928.49 & 17.15 & 972.62 & $3,191.59$ & 0.33 & 0.14 & 0.56 \\
\hline
\end{tabular}

tem, which has been observed as insufficient to retain household deposits and encourage lending under financial instability. Despite the gradual growth of the household deposit portfolio in recent years (Table 1), the level of penetration of deposit services in general (retail and corporate deposits to GDP) is lower, compared to the post-crisis years 2008 and 2009. This is additionally explained by the distrust of the population in the domestic banking system. The level of quality of financial products and services dropped in 2009, 2011 and 2015-2019, caused by the decrease of individuals' deposit portfolio and the reduction in lending. The ratio of net retail and corporate loans to GDP was $0.71 \%$ in 2008 , whereas in 2020 , the ratio changed to $0.14 \%$. The share of noncash transactions in the total volume of transactions using payment cards has been constantly growing: in $2008-0.05 \%$, while in $2020-0.56 \%$. This demonstrates the technologicalization of financial products and services, and consequently, consumers are more willing to prefer non-cash payments (and for more significant amounts), regardless of the crisis signs in the economy.

Based on the findings, it is recommended, first and foremost, to identify and develop financial products and services, which meet different target groups. Strengthening financial inclusion calls not only for expansion of the access but for diversification of the range of financial products and services as well. Secondly, merely broad access is not enough, and an appropriate level of financial literacy is required to stimulate demand for them. The authorities should also regularly assess the level of financial knowledge of individuals and their awareness of the proper usage of financial instruments. Less-educated groups, such as women, young people, the elderly, and the low-income, should be targeted while implementing financial education programs adapted to participants' needs. Thirdly, financial inclusion is inversely affected by the level of financial exclusion arising from the regulatory imbalances. The enhancement of consumer protection programs and effective supervision of financial institutions is seen as a prerequisite for financial inclusion and dissolving the distrust barrier to the financial services demand. Building confidence in financial institutions by increasing the sum of state-guaranteed deposits and ensuring the banking system's stability is also the condition for increasing the usage of financial products services. Finally, to deepen financial inclusion, regulators need to monitor the extent and severity of involuntary financial exclusion when users "drop out" of financial relationships due to regulatory imperfections or market barriers. 


\section{CONCLUSION}

This paper has estimated the level of financial inclusion of the Ukrainian economy, which remains medium. Upon the research results, during 2008-2020, the dynamics of the three-dimensional aggregate index of financial inclusion with the equivalent weight of sub-indices was fluctuant during the crisis and post-crisis years. A higher level of financial inclusion was observed in 2012, 2013, and 2020 (namely $0.55-0.56$ in the range of 0 and 1). From 2015 (0.38) till 2018 (0.39), a lower level was marked during the withdrawal of banks from the market, conducted by the National bank of Ukraine as a reform aimed at rehabilitating the banking system. However, such actions worsened the level of quality and usage of financial products and services by the population.

Despite the significant intensification of non-cash payments, improving the quality and expansion of banks' acquiring networks, today the financial inclusion level is slightly higher than in the pre-crisis 2008. Specifically, the level of usage and quality indicators are insufficient in the background of broadening access due to public distrust in the financial system.

Thus, the conducted retrospective analysis indicates the need to strengthen all dimensions of the financial inclusion of the Ukrainian economy, the deterioration of which may be the basis for closer monitoring by regulators over the progress in spreading financial products and services. Further research can focus on the impact of financial inclusion on income inequality.

\section{AUTHOR CONTRIBUTIONS}

Conceptualization: Yuliia Shapoval.

Formal analysis: Yuliia Shapoval.

Funding acquisition: Andrii Shkliar, Oleksii Shpanel-Yukhta, Kateryna Gruber.

Investigation: Yuliia Shapoval, Andrii Shkliar, Oleksii Shpanel-Yukhta, Kateryna Gruber.

Methodology: Yuliia Shapoval.

Project administration: Andrii Shkliar.

Software: Oleksii Shpanel-Yukhta.

Supervision: Andrii Shkliar.

Validation: Kateryna Gruber.

Visualization: Oleksii Shpanel-Yukhta.

Writing - original draft: Yuliia Shapoval.

Writing - reviewing \& editing: Kateryna Gruber.

\section{REFERENCES}

1. Amidzic, G., Massara, A., \& Mialou A. (2014). Assessing countries' financial inclusion standing - a new composite index (IMF Working Paper No. 36). Retrieved from https://www.imf.org/external/ pubs/ft/wp/2014/wp1436.pdf

2. Anufriieva, K., \& Shapoval, Y. (2019). Verbal interventions of the National Bank of Ukraine: The impact of exchange rate. Journal of International Studies, 12(3), 92-108. https://doi. org/10.14254/2071-8330.2019/12$3 / 8$
3. Beck, T., Demirgüç-Kunt, A., \& Honohan, P. (2009). Access to Financial Services: Measurement, Impact, and Policies. The World Bank Research Observer, 24(1), 119-145. https://doi.org/10.1093/ wbro/lkn008

4. Berezhna, L. V., \& Snytuk, O. I. (2019). The Path to the Sustainable Financial Inclusion in Ukraine: Analysis of the Current Issues. Accounting and Finance, 2(84), 71-80. (In Ukrainian). https://doi. org/10.33146/2307-9878-20192(84)-71-80
5. Camara, N., \& Tuesta D. (2014). Measuring Financial Inclusion: A Multi-dimensional Index (BBVA Working Paper No. 14/26). Retrieved from https://www. bbvaresearch.com/wp-content/ uploads/2014/09/WP14-26_Financial-Inclusion.pdf

6. Charkravarty, S.R., \& Pal, R. (2010, March). Measuring financial inclusion: an axiomatic approach (IGIDR Working Paper No. WP2010-003). Retrieved from http:// www.igidr.ac.in/pdf/publication/ WP-2010-003.pdf 
7. Chen, R., \& Divanbeigi, R. (2019) Can Regulation Promote Financial Inclusion? (World Bank Policy Research Working Paper No. 8711). Retrieved from http://hdl. handle.net/10986/31179

8. Claessens, S., \& Rojas-Suarez, L. (2016, March). Financial Regulations for Improving Financial Inclusion. A CGD Task Force Report. Retrieved from https://www.cgdev.org/publication/ft/financial-regulations-improving-financial-inclusion-brief

9. Deposit Guarantee Fund. (2020). Perevazhna bilshist hromadian Ukrainy za ostanni 2 roky ne mala problem $z$ bankamy - rezultaty opytuvannia Fondu harantuvannia vkladiv [The vast majority of Ukrainian citizens have not had problems with banks in the last 2 years - the results of a survey by the Deposit Guarantee Fund]. Press release. (In Ukrainian). Retrieved from https://www.fg.gov. ua/articles/47983-perevazhnabilshist-gromadyan-ukrani-zaostanni-2-roki-ne-mala-problemz-bankami--rezultati-opituvannya-fondu-garantuvannya-vkladiv.html

10. Dudynets, L. A., \& Vernei, O. E. (2018). Financial inclusion and its determinants. Socioeconomic problems of the modern period of Ukraine, 2(130), 8-13. (In Ukrainian). Retrieved from http://dspace.ubs.edu.ua/jspui/ handle/123456789/1760

11. International Monetary Fund (IMF). (2021). FAS country data. Retrieved from https://data.imf. org/regular.aspx?key=61063966

12. Kornivska, V. O. (2020). Instytutsiini ryzyky finansovoi inkliuzii [Institutional risks of financial inclusion]. Ekonomichna teoriya-Economic Theory, 4, 45-64. (In Ukrainian). https://doi. org/10.15407/etet2020.04.045

13. Menyelim, C. M., Babajide, A. A., Omankhanlen, A. E., \& Ehikioya, B. I. (2021). Financial Inclusion, Income Inequality and Sustainable Economic Growth in Sub-Saharan African Countries. Sustainability, 13(4), 1780. https:// doi.org/10.3390/su13041780
14. Ministry of Infrastructure of Ukraine. (2021). Ukrposhta prodovzhyt zabezpechuvaty 3.5 mln pensioneriv svoiechasnoiu dostavkoiu pensii dodomu, - Vladyslav Kryklii [Ukrposhta will continue to provide 3.5 million pensioners with timely delivery of pensions home, - Vladyslav Krykliy]. Press release. (In Ukrainian). Retrieved from https://mtu. gov.ua/news/32717.html

15. Mukherjee, S., \& Sood, K. (2020). Triggers and Barriers of Financial Inclusion: A Country-Wise Analysis. Asian Economic and Financial Review, 10(9), 970-988. https://doi.org/10.18488/journal. aefr.2020.109.970.988

16. National Bank of Ukraine (NBU). (2021). Official site. Retrieved from https://bank.gov.ua

17. Naumenkova, S. V. (2014). Finansova inkliuzyvnist ta problemy zabezpechennia dostupu naselennia do bazovykh finansovykh posluh v Ukraini [Financial inclusiveness and problems of ensuring access of the population to basic financial services in Ukraine]. Visnyk Natsionalnoho banku Ukrainy - Bulletin of the National Bank of Ukraine, 11, 31-37. (In Ukrainian). Retrieved from http://nbuv.gov.ua/ UJRN/Vnbu_2014_11_15

18. Nuzzo, G., \& Piermattei S. (2019). Measuring financial inclusion in the main euro area countries: the role of electronic cards (Occasional Papers No. 504). Questioni di Economia e Finanza, Bank of Italy. Retrieved from https://www. bancaditalia.it/pubblicazioni/ qef/2019-0504/QEF_504_19.pdf

19. Park, C.-Y., \& Mercado, Jr. R. (2018). Financial inclusion: new measurement and cross-country impact assessment (ADB Economics Working Paper Series No. 539). http://dx.doi.org/10.22617/ WPS189270-2

20. Prymostka, L., Krasnova, I., Prymostka, O., Nikitin, A., \& Shevaldina, V. (2020). Financial inclusion in Ukraine: determinants and evaluation. Financial and Credit
Activity Problems of Theory and Practice, 2(33), 500-512. http://doi. org/10.18371/fcaptp.v2i33.207218

21. Sarma, M. (2008). Index of financial inclusion (ICRIER Working Paper No. 215) Retrieved from http://www.icrier.org/pdf/Working_Paper_215.pdf

22. Sarma, M. (2012). Index of Financial Inclusion - A measure of financial sector inclusiveness (Berlin Working Papers No. 07/2012). Retrieved from https:// finance-and-trade.htw-berlin. de/fileadmin/HTW/Forschung/ Money_Finance_Trade_Development/working_paper_series/ wp_07_2012_Sarma_Index-ofFinancial-Inclusion.pdf

23. Shapoval, Yu. I. (2020). Household usage of financial services around the world and Ukraine. Ukrainskyi sotsium - Ukrainian society, 4(75), 34-56. (In Ukrainian). https://doi. org/10.15407/socium2020.04.034

24. Ukrposhta. (2021). About Ukrposhta. Retrieved from https:// www.ukrposhta.ua/ua/proukrposhtu 